\title{
International Journal of Applied Sciences and Biotechnology
}

\author{
A Rapid Publishing Journal
}

ISSN 2091-2609

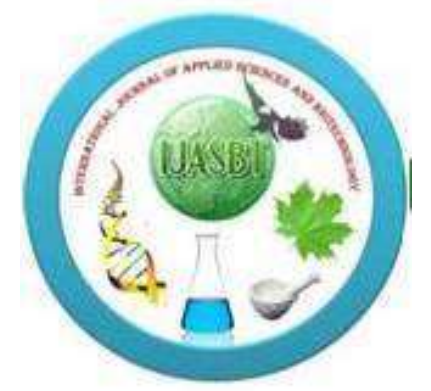

\section{Available online at:}

http://www.ijasbt.org

$\&$

http://www.nepjol.info/index.php/IJASBT/index

\section{Indexing and Abstracting}

CrossRef, Google Scholar, Global Impact Factor, Genamics, Index Copernicus, Directory of Open Access Journals, WorldCat, Electronic Journals Library (EZB), Universitätsbibliothek Leipzig, Hamburg University, UTS (University of Technology, Sydney): Library, International Society of Universal Research in Sciences (EyeSource), Journal Seeker, WZB, Socolar, BioRes, Indian Science, Jadoun Science, Jour-Informatics, Journal Directory, JournalTOCs, Academic Journals Database, Journal Quality Evaluation Report, PDOAJ, Science Central, Journal Impact Factor, NewJour, Open Science Directory, Directory of Research Journals Indexing, Open Access Library, International Impact Factor Services, SciSeek, Cabell's Directories, Scientific Indexing Services, CiteFactor, UniSA Library, InfoBase Index, Infomine, Getinfo, Open Academic Journals Index, HINARI, etc.

\section{CODEN (Chemical Abstract Services, USA): IJASKD}

Vol-2(3) September, 2014

Impact factor*: $\mathbf{1 . 4 2 2}$

Scientific Journal Impact factor": 3.419

SEM-Biotech

Publishing 


\title{
DISTRIBUTION AND SEASONAL ABUNDANCE OF POTATO TUBER MOTH: PHTHORIMAEA OPERCULELLA (ZELLER) (LEPIDOPTERA: GELECHIIDAE) IN NEPAL
}

\author{
${ }^{1}$ Nepal Agricultural Research Council \\ ${ }^{2}$ Institute of Agricultural and Animal Science \\ ${ }^{3}$ International Potato Center (CIP) \\ *Corresponding author email: frennaresh@yahoo.com
}

Y. P. Giri ${ }^{1}$, R. B. Thapa ${ }^{2}$, N. Dangi ${ }^{1 *}$, S. Aryal ${ }^{1}$, S. M. Shrestha ${ }^{2}$, S. B. Pradhan ${ }^{1}$, M. Sporleder ${ }^{3}$

\begin{abstract}
Annual monitoring of potato tuber moth (PTM) was made in 2008/09 in15 districts of Nepal to understand the distribution and seasonal abundance. The locally made pheromone trap was installed and observed in 24 hours intervals. The activity of PTM was observed in plain, mid hills (below 2200 masl) and high hill districts. The population of PTM was found more in mid-hills than in plain whereas PTM was absent in high hill districts. The highest average number of PTM was observed in May (480 $\pm 238 \mathrm{moth} / \mathrm{month})$ with no adult moths in October to December in plain whereas $522 \pm 174$ moth/month was observed in July and $18 \pm 4$ moth/month in December in mid-hills of Nepal. The seasonal abundance of PTM observed from March to July ( $74 \pm 63$ to $126 \pm 100$ moth/month) in Plain and March to October (191 \pm 157 to $104 \pm 60$ moth/month) in mid-hills. The understanding of PTM population dynamics could be useful to make suitable management decision.
\end{abstract}

Key words: Pheromone; Monitoring; Potato tuber moth; Potato

\section{Introduction}

Potato tuber moth is exotic pest of potato of Nepal reported in 1966 from Kathmandu valley (Anonymous, 1967). Due course of time, presence of potato tuber moth was reported from out of Kathmandu valley Rolpa, Dang and Salyan (Tiwary et al., 2006; Dangi et al., 2009). PTM was found more active in March to May in Kathmandu valley and its periphery causing 0.5 to $4 \%$ tuber infestation during harvest in 1984 to 1987 (Pradhan, 1987). Joshi (1989) mentioned trapping of PTM 113 moths/week in second week of March and 205 moths/week in May. Likewise Tiwary et al., (2006) reported 69 PTM in last week of August in Kathmandu and 76 moths in five days in May in Rolpa. Dangi et al., (2009) mentioned that activity of PTM increased with the crop maturity with an average of 44 to 49 moth/week in Dang and Salyan.

Chemical component of PTM sex pheromone (E4,Z7)tridecadienyl acetate (PTM 1) (Roelofs et al., 1975) and (E4,Z7,Z10)-tridecatrienyl acetate (PTM 2) (Persoons et al., 1976) has been identified. These two chemicals were synthesized (Voerman and Rothschild 1978) and blends ranging from 9:1 to 1:9 tested (Voerman and Rothschild 1978; Raman 1988). Most blends of the two chemicals were effective in catching male potato tuber moths.
Pheromone trap is an important tool for monitoring insect population. The trap baited with species-specific sex pheromone capture males which help to know the presence or absence and population dynamics of target insect from field populations. Herman et al., (1994) has reported that trap design, placement and chemical component of pheromone have great impact on trapping insect. These pheromone-baited traps are used to monitor relatively large areas for the presence of moth species. Monitoring of insect species is one of the important tools in wide range of crop and insect species. Synthetic sex pheromone is utilized to captures mostly male insect and it is species-specific (Harman et al., 2005). It is used for monitoring to determine migration, seasonal dynamics and spatial distribution (Starrat and McLeod 1982; Adams et al., 1989; Mitchell et al., 1989) of population of targeted insect species.

\section{Materials and Methodology}

Annual monitoring of PTM was made in three different agro-ecological zones (High-hill, mid-hill and plain ) from 3 , 9, and 3 districts from plain mid-hill and high hill of Nepal to understand the distribution and abundance of PTM in 2008/09 (Table 1). In each district one to five sites were selected and traps were installed in the potatoes storage for one year. The flight activity of PTM in potato fields was detected by using pheromone lure loaded with synthetic 
component consisting chemical component (E4,Z7)tridecadienyl acetate (PTM 1) and (E4,Z7,Z10)tridecatrienyl acetate (PTM 2) blends ranging from 9:1 to 1:9 tested. Lure impregnated septa (PTM-lure for potato tuber moth) and locally made water trap (5 liter capacity gallon locally available in commercial market), gallon was cut in the middle from both side and base was filled with tap water and one spoonful of detergent powder. The pheromone impregnate rubber septa (received from CIP) were hanged with the help of string just above the water. These septa from each trap were replaced in 4 weeks

Table 1: Monitoring sites of potato tuber moth in Nepal 2008/09

\begin{tabular}{|c|c|c|c|}
\hline Ecological regions & Districts (VDC/MN) & Trap number & Altitude (masl) \\
\hline \multirow{3}{*}{ Plain } & Kailali(Phulbari-1 and Manahariya-7) & 2 & 167 and 170 \\
\hline & Dang(Satbariya-5) & 1 & 236 \\
\hline & Jhapa (Charpane-3) & 1 & 121 \\
\hline \multirow{9}{*}{ Mid-hills } & Makawanpur (Daman-5 and Aghor-5) & 2 & 1745 and 2100 \\
\hline & Kavreplanchowk (Tukucha-5) & 5 & 1556 and 1602 \\
\hline & Kathmandu (Kasarthok-9 and Ramkot-3) & 2 & 1407 and 1450 \\
\hline & Argakhachi (Sandhikharka -7) & 1 & 985 \\
\hline & Dailekh (Gurashey-9) & 1 & 2145 \\
\hline & Salyan (Dhanbang-3) & 2 & 1490 \\
\hline & Parbat (Khurkot-2) & 1 & 800 \\
\hline & Kaski (Hemja-4) & 1 & 1080 \\
\hline & Ilam (Fikkal-6) & 1 & 1550 \\
\hline \multirow{3}{*}{ High hills } & Jumla (Dillichaur-7) & 1 & 2550 \\
\hline & Sindhupalchowk (Thumphakar, Jethal-6) & 2 & 1546 and 2460 \\
\hline & Solukhambu (Chaurikharka) & 1 & 2840 \\
\hline
\end{tabular}

Table 2: Ecological zone and district wise distribution of potato tuber moth in Nepal in 2008/09

\begin{tabular}{|c|c|c|c|}
\hline \multirow{2}{*}{ Ecological regions } & \multirow{2}{*}{ Districts } & \multicolumn{2}{|c|}{ Status of potato tuber moth } \\
\hline & & Presence & Absence \\
\hline \multirow{3}{*}{ Plain } & Kailali & $\oplus$ & \\
\hline & Dang & $\oplus$ & \\
\hline & Jhapa & $\oplus$ & \\
\hline \multirow{9}{*}{ Mid-hills } & Makawanpur & $\oplus$ & \\
\hline & Kavre & $\oplus$ & \\
\hline & Kathmandu & $\oplus$ & \\
\hline & Argakhachi & $\oplus$ & \\
\hline & Dailekh & $\oplus$ & \\
\hline & Salyan & $\oplus$ & \\
\hline & Parbat & $\oplus$ & \\
\hline & Kaski & $\oplus$ & \\
\hline & Ilam & $\oplus$ & \\
\hline \multirow{4}{*}{ High hills } & Jumla & & $\varnothing$ \\
\hline & Sindhupalchowk (Nigale) & & $\varnothing$ \\
\hline & Sindhupalchowk (Thumphakar) & $\oplus$ & \\
\hline & Solukhambu & & $\varnothing$ \\
\hline
\end{tabular}

$\oplus$ Indicates the presence of PTM in respective districts and $\varnothing$ means absence of PTM in respective districts interval. The number of moth trapped in the trap was observed in 24 hours interval in early morning (6-8 AM). The distribution and abundance of moth compared within the 15 districts to know the PTM distribution, abundance and seasonal dynamics. The average monthly data were log transformed and plotted over different months to know the pick population time in plain, mid-hill and high hill area of Nepal. In different growth stages of the potato crop and the three ecological zones weekly mean numbers of moths trapped per week were generated. 


\section{Result and Discussion}

\section{Distribution of PTM in Nepal}

The PTM was found in Kailali, Dang, Jhapa, Makawanpur, Kavreplanchowk, Kathmandu, Argakhachi, Salyan, Parbat, Kaski, Ilam and lower altitude of Sindhupalchowk. This pest was not observed in high hills (above 2000 masl). Among the 15 districts Jumla (2550 masl), Solukhumbu (2840 masl) found PTM free and in higher altitude of Sindhupalchowk (2460 masl). This pest was reported from central Nepal (Kathmandu valley) in 1966 for the first time (Entomology Section 1967), Rolpa districts of mid-western resign in 2006 (Tiwary et al., 2006), Dang and Salyan in 2009 (Dangi el al., 2009). This data showed that this exotic pest is spreading rapidly except in high hills of Nepal (Table 2).

\section{Seasonal abundance of PTM in Nepal}

Annual monitoring of PTM showed that PTM population activity got peak in May (480 \pm 238 moth/month) and adult moth was not trapped from October to December in plain area of Nepal (Fig 1). The activity of the PTM in mid-hill got peak in July (522 \pm 174 moth/month) and lowest number was observed in December (18 \pm 4 moth/month). This pheromone monitoring data indicates that the activity of PTM abundance was more from March to July ( $74 \pm 63$ to $126 \pm 100$ moth/month) in Plain whereas March to October (191 \pm 157 to $104 \pm 60 \mathrm{moth} /$ month) in mid-hill. Similarly, the activity was found low from August to January and November to February in plain and mid-hill region respectively. The average annual adult moth catch was $8.25 \pm 2.96,6.67 \pm 4.95$ in Jhapa and Kaski respectively. Similarly, the annual average adult catch in Kathmandu, Parbat, Kailali, Argakhachi, Dang, Makawanpur, Sindhupalchowk, Kavreplanchowk was $69.67 \pm 4.95$, $71.17 \pm 53.10,107.08 \pm 66.21,145.17 \pm 75.43,217.33 \pm 83.19$, $254.75 \pm 103.45, \quad 345.00 \pm 136.91$ and $583.42 \pm 183.78$ respectively.

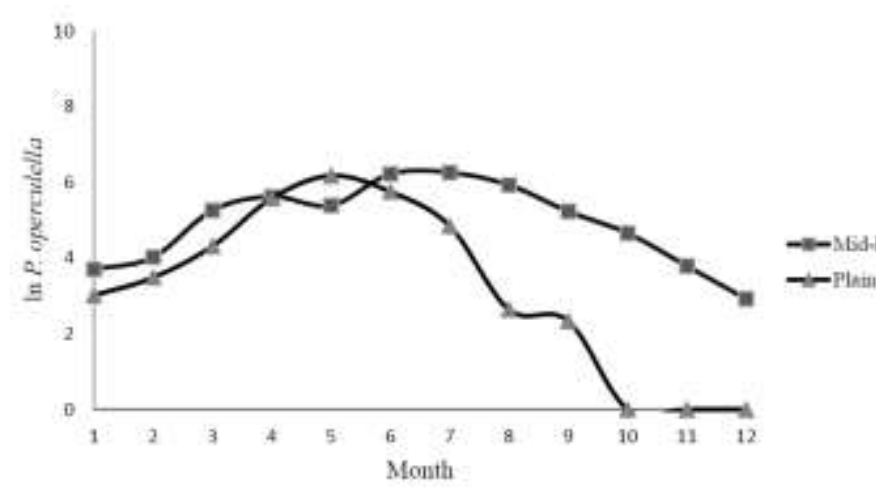

Fig. 1: Seasonal dynamics of PTM in plain and mid-hill districts of Nepal in 2008/09

The PTM population was found significantly more in Kavre plan chowk where farmer grow two season potato. The population starts increasing from February (191 moth/month) and got peak in April (1795 moth/month). The population remain nearly constant from April to July (1729 to $1295 \mathrm{moth} / \mathrm{month}$ ) and starts decreasing regularly from August to January (764 to 18 moth/month). Similarly, in Kathmandu the population remains nearly constant in February to April (120 to 100 moth/month) and May to January (69 to 63 moth/month) in which PTM got peak in May (150 moth/month) (Fig 2).

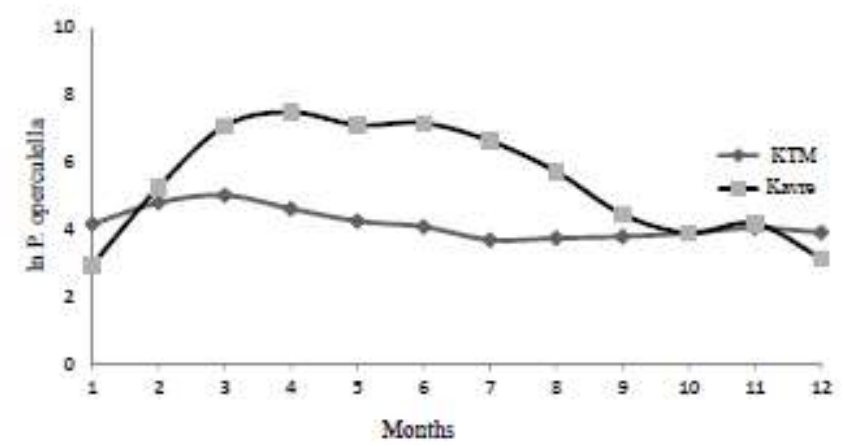

Fig. 2: Seasonal dynamics of PTM in Kathmandu and Kavreplanchowk districts of Nepal in 2008/09

The PTM population was foun more in Dang and Kailali in comparision of Jhapa. In Dang the PTM activity was observed more in June (806 moth/month) and less in September to December with no adult catch in trap whereas in Kailali the activity was found more in May (803 moth/month) and less in October to December with no adult catch. Similarly, the activity of PTM was found very low in Jhapa with highest catch 30 moth/month in August and without no adult catch from September to February (Fig. 3)

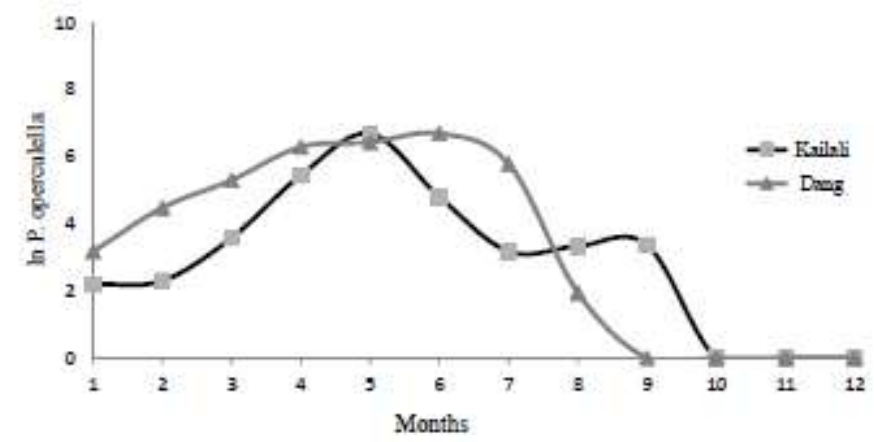

Fig. 3: Seasonal dynamics of PTM in Kailali and Dang districts of Nepal in 2008/09

The PTM population in mid hill region outside from Kathmandu valley was also found significantly different in different months. The peak activity with highest adult catch per month was found in June to August in Makanpur, Parbat, Argakanchi, and Kaski districts (Fig 4). The in these population in these locations remains very low from February to March in Makanpur, February to April in Parbat and Agarkachi and November to June in Kaski. The peak 
population was observed in August with 738 and 60 moth/month in Argakanchi and Kaski whereas, in June with 647 and 1079 moth/month in Parbat and Makawanpur respectively.

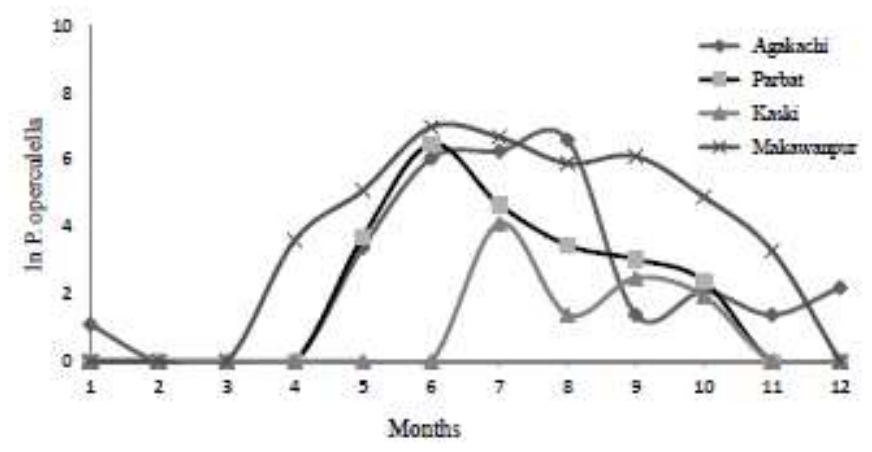

Fig. 4: Seasonal dynamics of PTM in mid-hill districts of Nepal in $2008 / 09$.

PTM monitoring using sex pheromone showed that activity starts from January and found more in March, April and May at 1984 to 1987 at Khumaltar, Kathmandu valley and Nala and Surbinayak Bhaktapur in 1987 (Pradhan, 1987). In 1986, spring potato cropping season, two distinct population peaks was found i.e. $113 \mathrm{PTM} /$ trap/week at second week of March and 205PTM/trap/week at entire May (Joshi, 1989) and Tiwary et al., (2006) mentioned 69 PTM/trap at last week of August in Kathmandu and 76 PTM/trap at May in five days of trap setting in Rolpa. The monitoring of PTM in standing crop showed that PTM population increased with the crop growth increment with 5.7 to $14.5 \mathrm{moth} /$ weekly at sprouting stage and 49.0 $( \pm 10.5), 44.6( \pm 11.1), 46.8( \pm 5.8)$ at tuber maturation stage in three different site of Dang respectively and $45.2( \pm 6.3)$ at Dhanwang-3, Salyan (Dangi et al., 2009).

Both Raman (1988) and Tamhankar \& Harwalkar (1994) tested a water trap and a funnel trap and found no significant difference in moth catch. However, Bacon et al. (1976) found water traps caught more moths than sticky traps. While Raman (1988) concluded that potato tuber moth pheromones could be an extremely useful tool in a potato tuber moth IPM programme, the research cited above showed that a number of trap-related factors can influence the catch of moths.

\section{Conclusion}

At present, potato tuber moth is a major pest of potato in storage condition in Nepal. This pest is distributed in midhills and plain areas. The abundance of the pest was found more in mid-hills where potatoes are grown twice a year. This pest is more problematic in stored potatoes harvested during May-June. The monitoring data shows the peak flying activity of potato tuber moth in the above mentioned region and districts. The distribution and activity of PTM is increasing in new areas over the time.

\section{Acknowledgement}

The outcome of the project was collaborative work between Nepal Agricultural Research Council (NARC) and International Potato Center (CIP), funded by the Ministry of Development and Cooperation (BMZ), Germany, and OPEC Fund for International Development. We are thankful to all the participant farmers, individuals, researchers and institutions who have contributed directly or indirectly to make the study success.

\section{Reference}

Adams, RG, Murray KD and Los LM (1989) Effectiveness and selectivity of sex pheromone lures and traps for monitoring fall armyworm (Lepidoptera: Noctuidae) adults in Connecticut sweet corn. Journal Economic Entomology, 82: 285-290.

Bacon OG, Seiber JN and Kennedy GG (1976) Evaluation of survey trapping techniques for potato tuberworm moths with chemical baited traps. Journal of Economic Entomology, 69: 569-572.

Dangi, N., Thapa RB, Giri YP and Sporleder M (2009) Insect diversity and potato insect pest severity in potato crop in Dang and Salyan districts of Nepal. M. Sc. Thesis, Institute of Agriculture and Animal Science (IAAS), Tribhuvan University, Rampur, Chitwan, Nepal.

Entomology Section (1967) Annual Report 1966-67. Entomology Section, Agricultural Education and Research Department, Jagadamba Bhawan, Lalitpur Nepal. Pp. 4.

Herman TJB, Clearwater TR and Triggs CM (2005) Impact of pheromone trap design, placement and pheromone blend on catch of potato tuber moth. New Zealand Plant Protection, 58: 219-223.

Joshi SL (1989) Comparative life cycle of the potato tuber moth, Phthorimaea operculella (Zeller) (Lepidoptera:Gelechiidae) on potato tubers and foliages and its economic loss in yield. Journal of entomological society of Nepal, 1: 59-69.

Mitchell, ER, Agee HR and Heath RR (1989) Influence of pheromone trap color and design on the capture of male velvet bean caterpillar and fall armyworm moths (Lepidoptera: Noctuidae). Journal of Chemical Ecology, 15: 1775-1784. DOI: 10.1007/BF01012265

Persoons CJ, Voerman S, Verwiel PEJ, Ritter FJ, Nooijen WJ and Minks AK (1976) Sex pheromone of the potato tuberworm moth, Phthorimaea operculella: Isolation, identification and field evaluation. Entomologia Experimentalis Applicata, 20: 289-300. DOI: $10.1111 /$ j.15707458.1976.tb02645.x

Pradhan RB (1987) Control of Potato Tuber Moth by Weeds. Report of National Potato Development Program (HMGINISATA). Lalitpur, Nepal. 18 pp

Raman KV (1988) Control of potato tuber moth Phthorimaea operculella with sex pheromones in Peru. Agriculture, Ecosystems and Environment, 21: 85-99. DOI: 10.1016/0167-8809(88)90141-7 
Roelofs WL, Kochansky JP, Carde RT, Kennedy GG, Henrick CA, Labovitz JN and Corbin VL (1975) Sex pheromone of the potato tuberworm moth, Phthorimaea operculella. Life Science, 17: 699-706. DOI: 10.1016/00243205(75)90524-X

Starrat AN and Mcleod DGR (1982) Monitoring fall armyworm, Spodoptera frugiperda (Lepidoptera:Noctuidae), moth population in southwestern Ontario with sex pheromone traps. Canadian Entomology, 114: 545-549. DOI: 10.4039/Ent114545-7

Tamhankar AJ and Harwalkar MR (1994) Comparison of a dry and water trap for monitoring potato tuber moth
Phthorimaea operculella Zeller. Entomology, 19: 163164.

Tiwari DB, Thapa RB, Shrestha SM and Joshi SL (2006) Field survey and monitoring of potato tuber moth, Phthorimaea operculella (Zeller) (Lepidoptera : Gelechiidae. Journal of Institute of Agricultural and Animal Science, 26:157-160.

Voerman S and Rothschild GHL (1978) Synthesis of the two components of the sex pheromone system of the potato tuberworm moth, Phthorimaea operculella (Zeller) (Lepidoptera: Gelechiidae) and fi eld experience with them. Journal of Chemical Ecology, 4: 531-542. DOI: 10.1007/BF00988917 